\author{
Mieczysław C. PACZKOWSKI OFM \\ (Wrocław - Toruń, UMK)
}

\title{
„OBCY” I „PRZYBYSZE” \\ Od statusu cywilno-prawnego do eklezjologii wyobcowania
}

Człowiek nierzadko odnosił wrażenie, że jego bytowanie na ziemi ma charakter przejściowy. Na podstawie tekstów biblijnych i refleksji teologicznej zrodziła się myśl, że na tym świecie prowadzi się życie pielgrzymów i obcych. Chrześcijaństwo wyraziło to $\mathrm{w}$ sposób bardzo jasny i dobitny: wierzący w Chrystusa są „w świecie”, ale nie są ,ze świata” (J 17, 11. 14. 16), ponieważ ich prawdziwa ojczyzna jest w niebie, skąd oczekują przyjścia jako Zbawiciela Jezusa Chrystusa (Flp 3, 20). Członkowie wspólnoty Kościoła nie mają na ziemi stałego miejsca pobytu, ale są w drodze ku przyszłej, prawdziwej ojczyźnie (Hbr 13, 14). Świadomość obcości i przejściowości była na początku podstawowym odczuciem tożsamości chrześcijańskiej. Tak pojęty status wiernych znalazł swoje uzasadnienie w literaturze starożytnej, od źródeł biblijnych począwszy.

1. Podstawy biblijne. Swój pierwszy list Piotr apostoł skierował do „wy-

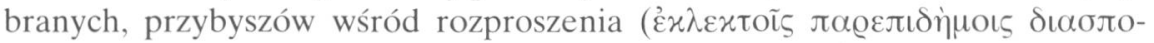

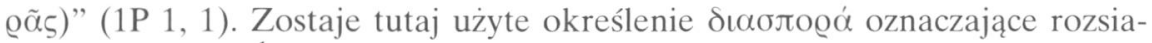
nie, rozproszenie ${ }^{1}$. Chrześcijanie są bowiem Bożym zasiewem, rozsianym po świecie ${ }^{2}$, aby w końcu cały świat stał się Bożą rolą, która przynosi owoce dobra. Nie ma w stosunku do świata wrogości czy pogardy; świat jest także Boży i Bóg „kocha świat” i chce „świat zbawić” (J 3, 16; 12, 47). To właśnie do chrześcijan w świecie skierowane są słowa zachęty: „W bojaźni spędzajcie czas swojego

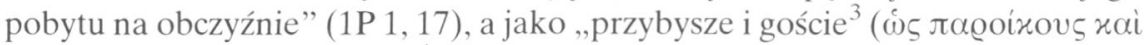
$\pi \alpha \varrho \varepsilon \pi \iota \delta \dot{\eta} \mu \nu \varsigma) "(1 \mathrm{P} 2,11)^{4}$ powinni oni powstrzymywać się od wszelkich cielesnych pożądań.

${ }^{1}$ Ten termin techniczny, oznaczający grupy Żydów zamieszkałych poza terenem Ziemi Obiecanej, zdobył popularność w okresie hellenistycznym, por. Pwt 28, 25 (LXX); 30, 3.

2 Jako dıơлo@á kwalifikuje chrześcijan także Jk 1, 1.

${ }^{3}$ Niektórzy specjaliści są zdania, że te dwa słowa należy tłumaczyć za pomocą równoznacznych określeń „cudzoziemcy” i „obcy”, por. np. E. Bosetti, I cristiani come stranieri nella prima lettera di Pietro, w: I. Cardellini (red.), Lo „straniero” nella Bibbia, Bolonia 1996, 317-334.

${ }^{4} \mathrm{Na}$ temat tego wersetu por. M. De Jonge, Vreemdelingen en bijwoners: einige opmerkingen 
Na kartach Starego Testamentu wzmianki o statusie pielgrzyma i wędrowca pojawiają się w kontekście historii patriarchów. Abraham ${ }^{5}$, chcąc nabyć na własność grotę w Makpela, oświadcza Hetytom: „Mieszkam wśród was jako

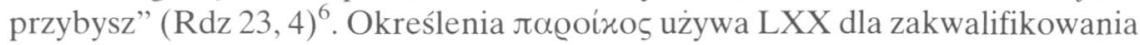
statusu patriarchów, na przykład Abrahama w Egipcie, a także Izaaka, a później Jakuba w Hebronie (Rdz 35, 27). Modlitwa Psalmisty dotyczy natomiast prośby o odrobinę radości i szczęścia przed opuszczeniem tego świata, gdzie jest on ,gościem i [...] przechodniem” (Ps 39, 13). Natchnieni autorzy wzmiankują przodków, mając na uwadze Abrahama, o którym wiadomo, ze przez wiarę całe swe życie żył jako pielgrzym i obcy $(\operatorname{Rdz} 15,13)^{7}$. W przepowiadaniu apostoła Pawła pojawia się uwaga, że Izrael był „na obczyźnie w ziemi egipskiej" $(\mathrm{Dz} 13,17)^{8}$. Życie wierzących w Chrystusa jest przedstawione w Nowym Testamencie jako ,droga” (Dz 9,2).

$1 \mathrm{P} 2,11$ jest jedynym tekstem nowotestamentowym, w którym dwa określenia z Rdz 23, 4 i Ps 39, 13 występują razem. Pierwsze z tych określeń ( $\pi \alpha \varrho o u x i \alpha)$ pojawia się dość często zarówno w Starym, jak i w Nowym Testamencie $^{9}$ dla oznaczenia prowizorycznego i czasowego przebywania ${ }^{10}$. Słowem $\pi \propto \varrho \circ \varkappa \varepsilon \dot{\varepsilon} \omega$ określano więc mieszkającego obok, w pobliżu, nie wewnątrz, ale na obrzeżach. Stąd termin đóøoıxos oznacza także kogoś, kto mieszka w jakimś miejscu przez krótki czas, człowieka przechodzącego, również wygnańca z własnej ojczyzny. Do znaczenia prowizoryczności dołącza się pojęcie przejściowości. Rzeczywiście, ktoś, kto jest gościem w jakimś mieście, nie posiada wszystkich praw prawdziwych mieszkańców; dlatego лó@oıxos oznacza także

naar aanleiding van I Petr. 2,11 en verwante teksten, NThT 11 (1957) 18-36; M. Adinolfi, Stato civile dei cristiani „forestieri e pellegrini” (1 Petr. 2, 11), „Antonianum” 42 (1967) 420-434. To samo studium zostało opublikowane w: M. Adinolfi, Questioni bibliche di storia e storiografia, Brescia 1969, 191-208; R. Lugo Rodríguez, Forasteros y emigrantes (1 Pe. 2, 11): reflexión bíblica sobre la naturaleza de los cristianos en cuanto peregrinos, ,QOol” 11 (1996) 35-46.

${ }^{5}$ Powołanie Abrahama (Rdz 12,1) stało się paradygmatem człowieka wiary jako „wychodźcy” i ,pielgrzyma”. Ta perykopa biblijna została przywołana przez Szczepana w jego mowie przed Sanhedrynem $(\mathrm{Dz} 7,1)$. Tradycja chrześcijańska bardzo wcześnie połączyła wędrówkę Abrahama z drogą ucznia Chrystusa wg słów Mt 19, 6: „Każdy, kto dla mego imienia opuści dom, braci lub siostry, ojca lub matkę, dzieci lub pole, stokroć tyle otrzyma i życie wieczne odziedziczy"; por. również Mt 16, 24.

6 Tekst LXX mówi o „cudzoziemcu” i ,przechodniu”.

7 Por. Hbr 11, 9; do tej myśli nawiązują Dz 7, 6.

8 Wątki teologiczne związane $\mathrm{z}$ epopeją wyjścia z niewoli egipskiej stały się kluczowe dla wspólnoty chrześcijańskiej w różnych epokach, por. przede wszystkim J. Moingt, Une théologie de l'exile, w: C. Geffre, Michel de Certeau ou la différence chrétienne, Paris 1991, 131-156.

9 We współczesnych przekładach $\pi$ $\alpha \varrho \circ$ xi $\alpha$ brzmi „obczyzna” (wygnanie). Sięgając do etymologii należy zauważyć, że przysłówek $\pi \alpha \varrho \alpha ́$ oznacza „obok”; zaś oixi $\alpha$ jest rzeczownikiem określającym mieszkanie.

10 Por. rozważania R. Cantalamessa, Eucharystia nasze uświęcenie. Tajemnica Wieczerzy Pańskiej, tłum. A.J. Zębik, Warszawa 2004, 166. 
obcego w przeciwieństwie do mieszkańca na pełnych prawach. Dla Żydów był to obcokrajowiec, który przez wspólne zamieszkiwanie z nimi doszedł do ograniczonego jedynie współudziału w ich prawach i przywilejach ${ }^{11}$. W Starym Testamencie jest mowa o przywilejach, jakimi winni cieszyć się uchodźcy i przybysze. Wynikało to z samych dziejów Izraela - obcego w Egipcie ${ }^{12}$.

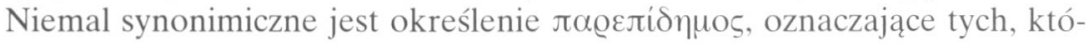
rzy są na zewnątrz zgromadzenia ludu. W sferze języka łacińskiego wchodzi się w kontekst pojęcia „peregrinare” używanego przez autorów chrześcijańskich w odniesieniu do wędrówki ku odwiecznej ojczyźnie. Kategoria ludzi określanych mianem ,peregrini” była dobrze znana starożytnym chrześcijanom. Chodziło o ,przemieszkujących obcych” i ,przechodniów”, " Z terminem

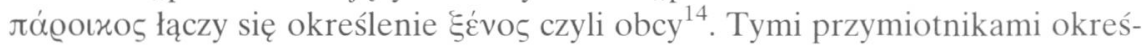
lano w Starym Testamencie grupy ludzi, którzy nie wchodzili w szeregi narodu wybranego ${ }^{15}$. Greckie określenie छ́vvos ma charakter ambiwalentny: z jednej strony oznacza obcego, cudzoziemca, a więc potencjalne zagrożenie, a z drugiej gościa, pomieszkującego obok ${ }^{16}$. Słownictwo greckie użyte także w thumaczeniu LXX jest więc mniej radykalne od terminologii hebrajskiej, w której obok znaczenia etniczno-politycznego, istniała przede wszystkim pejoratywna kolokacja określenia „cudzoziemiec”, pojmowanego jako wróg i przeciwieństwo Izraela. Nie wyklucza to jednakże innej kategorii cudzoziemców mieszkających razem z Judejczykami. Ich status był czymś pośrednim pomiędzy rodowitymi członkami narodu wybranego, a wrogami z obcych narodów ${ }^{17}$.

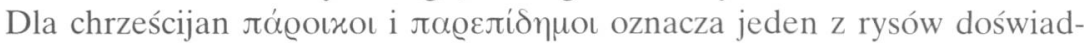
czenia wiary, w kontekście czasu i przestrzeni, poddanych władztwu Boga. Od Niego posiadamy dar życia w przestrzeni i w czasie. Wyraża to modlitwa króla Dawida: „Od Ciebie wszystko pochodzi [...]. Jesteśmy bowiem pielgrzymami przed Tobą i przychodniami, jak byli wszyscy przodkowie nasi; dni nasze jak

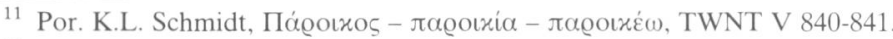

12 Por. R. Martin-Achad, „Gur”, dimorare come forestiero, w: Dizionario teologico dell'Antico Testamento, I, Torino 1978, 357.

13 Słowo peregrinus etymologicznie wywodzi się od peregre = „,daleko”, ,na zewnątrz” (per agros $=$,,przez pola”, ,,poza miastem”).

${ }^{14}$ Przykład użycia tego słowa to Ef 2, 19: „Nie jesteście już obcymi i przychodniami, ale jesteście współobywatelami świętych i domownikami Boga".

15 Por. Rdz 23, 4; 15, 13; Wj 2, 22; Ps 38, 13; zob. J. Szlaga, ,ZZudowani na fundamencie apostołów i proroków”. Problemy egzegetyczne Ef 2, 19-22, CT 46 (1976) z. 1, 46. Chodzi

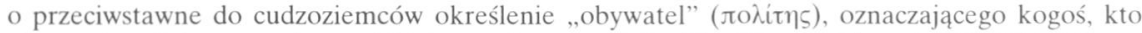

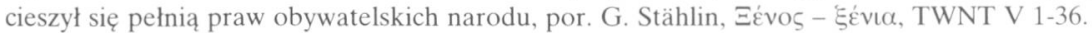

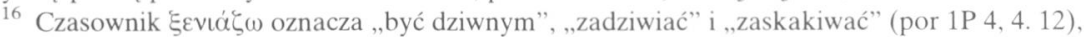
lecz również „przyjąć” i ,gościć” (por. Dz 10, 6. 18. 23. 32; 21, 16; 28, 7).

17 Por. D. Kellermann, Gûr, ger gerût me gûrîm, w: G. Botterweck - H. Rinnigren, Grande lessico dell'Antico Testamento, I, Brescia 1988, 2008; I. Cardellini, Stranieri e immigrati residenti in una sintesi di teologia storico-biblica, „Rivista Biblica Italiana” 2 (1992) 151. 
cień na ziemi mijają bez żadnej nadziei” (1Krn 29, 14-15). Od konstatacji na temat ograniczoności ludzkiego istnienia na ziemi przechodzi się do świadomości pielgrzymowania do ojczyzny niebiańskiej. Reprezentatywny pod tym względem jest znowu przykład Abrahama, który „przez wiarę przywędrował do Ziemi Obiecanej, jako ziemi obcej” (Hbr 11, 9).

W koncepcji Pawłowej nie chodzi bynajmniej o uwydatnienie różnic pomiędzy „przechodniami” i „obcymi”, lecz o elementy, które ich łączyły z narodem wybranym, nie stanowiącym z nimi jednej zwartej społeczności, zrównanej we wszystkich prawach. Szerszą perspektywę ujawnia tekst Hbr 11, $13^{18}$. Należy jednak dodać, że w przeciwieństwie do $\mathrm{Hbr}^{19}$ według 1P mieszkaniem chrześcijan nie jest przyszły świat, lecz wspólnota Kościoła. W liście Piotrowym brak wyrażeń odnoszących się do obywatelstwa $\pi$ ó $\lambda \varsigma^{20}$. Stąd też obraz ten należałoby uzupełnić wątkami Pawłowymi. Według wizji Apostoła narodów

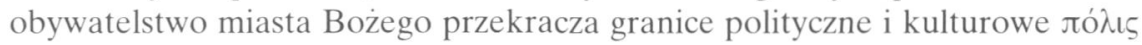
oraz tworzy więzi braterskie między wszystkimi. U autorów chrześcijańskich jest to podstawowe uzupełnienie kwestii przejściowości i wyobcowania na tym świecie, doświadczanych przez wierzących w Chrystusa. To powód, dla którego

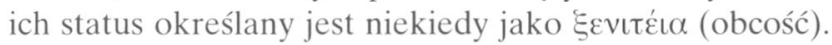

„Rozproszenie”, „wyobcowanie”, „tymczasowość” to cechy uważane za konstytutywne dla wspólnoty chrześcijańskiej, obecnej w pogańskim świecie. W tym momencie należałoby się zastanowić, czy metafora „obcych” i „przybyszów" nie ma uzasadnienia w rzeczywistej pozycji społecznej chrześcijan w świecie grecko-rzymskim. Być może chodziło również o zakwalifikowanie chrześcijan jako należących do niższej klasy społecznej, ponieważ nie posiadali praw obywatelskich ${ }^{21}$, stąd określenie zbudowano być może na rzeczywistym statusie cywilno-społecznym chrześcijan, wywodzących się z kręgów judaistycznych. Chociaż Kościoła nie stanowili wyłącznie wierni wywodzący się z żydostwa, jednak nurt judeochrześcijański przeważał początkowo we wspólnotach Azji Mniejszej. Status wyznawców judaizmu, który odziedziczyli w sporej części chrześcijanie, miał rysy szczególne. Stąd też adresaci listów Pawłowych i 1P byli nie tylko w sensie przenośnym .obcymi” i ,przybyszami”22.

18 Por. Hbr 11, 13: „W wierze pomarli oni wszyscy, nie osiągnąwszy tego, co im przyrzeczono, lecz patrzyli na to z daleka i pozdrawiali, uznawszy siebie za gości i pielgrzymów na tej ziemi”.

19 Por. K. Niederwimmer, Vom Glauben der Pilger. Erwägungen zu Hebr 11, 8-10 und 13-16, w: S. Kreuzer - K. Lüthi - G. Sauer, Zur Aktualität des Alten Testaments. Festschrift für Georg Sauer zum 65. Geburtstag, Bern 1992, 121-131. To samo studium ukazało się ponadto w: W. Pratscher - M. Öhler, Quaestiones theologicae. Gesammelte Aufsätze, Berlin 1998, 207-216.

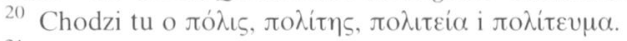

21 W 1 Kor 1, 26 został ukazany przekrój społeczny pierwszej wspólnoty chrześcijańskiej: „Niewielu tam mędrców według oceny ludzkiej, niewielu możnych, niewielu szlachetnie urodzonych”.

22 Por. J.H. Elliott, 1 Peter (Anchor Bible), New York 2000, 94-97, 312-313, 457-462, spec. 313; zob. tenze, A Home for the Homeless: a sociological exegesis of 1 Peter, its situation and strategy, Philadelphia 1981, 21-100. 
Orędzie chrześcijańskie urzeczywistniało się w różnych warunkach społeczno-kulturowych ${ }^{23}$. Stąd też nie negowano środowiska, w którym żyli wierni, akceptując grupy społeczne, strukturę polityczną i ukierunkowanie kulturowe. Jednak w imię chrześcijańskiej nowości różnice klasowe zostały osłabione i powoływano się na braterstwo wszystkich chrześcijan ${ }^{24}$. Stąd też określenia „obcy” i „przybysze” przybrały wyraźny odcień metaforyczny, pozwalający na operowanie nimi także w zupełnie innej sytuacji Kościoła po Przełomie Konstantyńskim.

\section{Starożytne $\pi \dot{\lambda} \lambda_{\iota}$, jej obywatele, cudzoziemcy i żydowscy mieszkańcy.} Według Arystotelesa miasto-państwo ( $\pi$ ó $ı \varsigma$ ), ,jest pewną liczbą obywateli"25. Musi to być jednak „ogół... ludzi, odpowiednio wielki, by zapewnić wszystko, co do życia potrzebne, w wystarczającej mierze"26. To zbiorowość ludzka

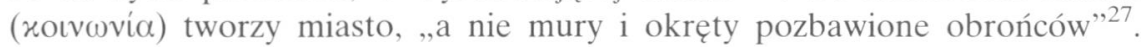
Arystoteles uważał państwo za najwyższą i najbardziej doskonałą formę ludzkiego współżycia, a nazywając człowieka „bytem społecznym” wskazał, że istota człowieczeństwa polega na życiu państwowym, na rozkazywaniu i posłu-

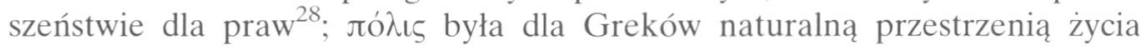
i działalności, a nie, jak można by sądzić, wyłącznie aparatem władzy i struktu-

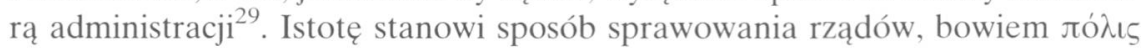

${ }^{23}$ W obrębie $\pi$ ó̀ı chrześcijanie kultywowali i głosili patriarchalizm, por. D.L. Balch, Early Christian Criticism of Patriarchal Authority: I Peter 2:11 - 3:12, „Union Seminary Quarterly Review” 39 (1984) 161-173.

${ }^{24}$ Por. D. Senior, The Conduct of Christians in the World (2:11-3:12), „Review Expository” 79 (1982) 427-438.

${ }^{25}$ Politica II 1274b, thum. L. Piotrowicz: Arystoteles, Polityka, Biblioteka Klasyków Filozofii, Warszawa 1964, 92.

${ }^{26}$ Tamże III 1275 b, thum. Piotrowicz, s. 97.

27 Thucydides, Bellum Peloponnesiacum VII 77, tłum. własne, por. tłum. K. Kumaniecki: Tukidydes, Wojna peloponeska, BN II 225, Wrocław 1991, 570; zob. też Plato, Respublica II 369c, tłum. W. Witwicki: Platon, Państwo - Prawa, Kęty 1999, 63: „Zbieramy wielu ludzi do jednego siedliska, aby wspólnie żyli i pomagali jeden drugiemu i to wspólne mieszkanie nazwaliśmy imieniem Państwa”. O tym, że definicja ta ugruntowała się w chrześcijaństwie świadczy zdanie Hieronima ze Strydonu, dla którego idealnym i duchowym miastem (Jerozolimą) ,nie są nazwane kamienie i budowle [...], ale jego mieszkańcy (Hierusalem non saxa et aedificia civitatis sed habitatores vocat)", por. In evangelium Matthaei IV 23, 37-39, PL 26, 174-175.

${ }^{28}$ Por. T. Sinko, Zarys literatury greckiej, I, Warszawa 1959, 898.

${ }^{29}$ Chodzi o jeden wspólny organizm państwowy powstały przez połączenie kilku gmin. Proces przejścia od ustroju rodowego do organizacji państwowej, jaką była лó̀ıร, dokonał się w XII-VIII wieku przed Chrystusem. Grecka лó $\lrcorner 5$ była centrum handlowym, politycznym, kulturalnym i siedzibą władz. Utrata niepodległości przez Grecję po bitwie pod Cheroneą w r. 338 przed Chr. oznacza upadek tej instytucji jako jednostki politycznej. Odnośnie do tej tematyki por. W Kornatowski, Zarys dziejów myśli politycznej starożytności, Warszawa 1968; G.L. Seidler, Myśl polityczna starożytności, Kraków 1961. To właśnie ten filozof stworzył ponadhistoryczną koncepcję politei, mającą swe oparcie w odwiecznej i niezmiennej idei państwa. 
była suwerenną społecznością, która rządzi się i funkcjonuje nie tworząc struktur państwowych odrębnych od społeczeństwa.

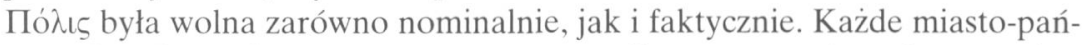
stwo regulowało swoje sprawy wewnętrzne według praw ustalonych przez obywateli i uważało się za uniezależnione wobec nacisków zewnętrznych. Mury miasta były symbolem tej autonomii ${ }^{30}$. Obywatele byli członkami zgromadze-

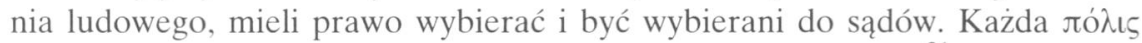
posiadała więc władzę ustawodawczą, wykonawczą i sądową ${ }^{31}$. Jednak nie wszyscy mieszkańcy miasta byli jego obywatelami ( $\pi 0 \lambda \iota \tau \alpha i$, cives) czyli cieszącymi się wszystkimi prawami i przywilejami oraz spełniającymi określone obowiązki ${ }^{32}$. Oprócz niewolników istniały inne kategorie osób osiadłych w miastach

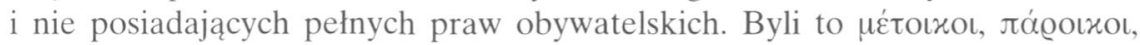

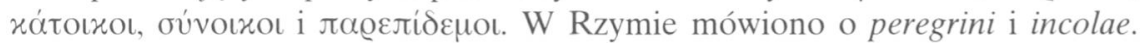
Byli oni pozbawieni niektórych praw, podlegali restrykcjom i specjalnym podatkom oraz nakładano na nich kary niestosowane wobec obywateli. Mieszkańcy nie posiadający obywatelstwa mogli jednak zbierać się w kolegia (ž@ovos,

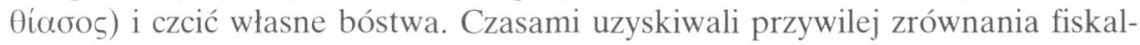
nego z obywatelami i posiadania nieruchomości. Ideałem było jednak uzyskanie stałego obywatelstwa. По kretem zgromadzenia obywateli. Obywatelstwo nadawano w uznaniu zasług dla miasta lub, z powodu deficytów finansowych, sprzedawano bogatym osobom ${ }^{33}$. Bardzo surowo karano tych, którzy przywłaszczali sobie obywatelstwo jakiegoś miasta. W Atenach groziła za to przestępstwo kara popadnięcia w niewolę ${ }^{34}$, a w Rzymie ścięcie ${ }^{35}$. Przed epoką Aleksandra Wielkiego miasta greckie nie nadawały obywatelstwa obcym, strzegąc w ten sposób swojej helleńskiej czystości. Dopiero czasy hellenistyczne przyniosły liberalizację w tej kwestii.

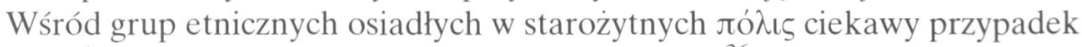
tworzyli Żydzi. Diaspora hebrajska była bardzo liczna ${ }^{36}$. Wspólnoty żydowskie

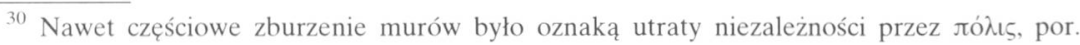
Josephus Flavius, Bellum Judaicum IV 117.

31 Por. Aristoteles, Politica IV 1297b-1298a, thum. Piotrowicz, s. 182: „Wszystkie ustroje mają trzy części składowe, toteż mądry prawodawca musi się nad tym zastanowić, co jest dla każdej z nich pożyteczne [...]. Jedną z tych trzech części jest czynnik obradujący nad sprawami państwowymi, drugą czynnik rządzący (bierze się przy tym pod uwagę, jakie winny być urzędy, jaki ich zakres władzy i jaki sposób ich wyboru), trzecią zaś czynnik sądzący. Czynnik obradujący rozstrzyga o pokoju i wojnie, o zawarciu i zerwaniu przymierza, o prawach, o [karze] śmierci, wygnania i konfiskaty mienia, o wyborze urzędników i ich kontroli".

32 Por. tamże IV 1297 b.

33 Por. niektóre przykłady wg M. Adinolfi (Stato civile dei cristiani ,forestieri e pellegrini”, S. 426).

${ }^{34}$ Por. Demosthenes, Contra Timotheum 49, 66.

35 Por. Suetonius, Claudius 25, 3.

36 Por. listę Filona w Legatio ad Caium 36. Dzieje diaspory w basenie Morza Śródziemnego 
zwane $\pi$ o $\lambda$ i $\varepsilon v \mu \alpha^{37}$ posiadały nie tyle autonomię polityczną, co wolność w praktykowaniu religii. Interpretacja źródeł odnoszących się do tej kwestii jest sprawą wielce skomplikowaną, bowiem dysponujemy świadectwami raczej tendencyjnymi, które wyszły spod pióra autorów niechętnych Żydom bądź są swoistą apologią judaizmu. Autorzy często popadają w sprzeczności, jak w przypadku opisu statusu Hebrajczyków osiadłych w Cyrenie. Józef Flawiusz pisze:

„Mieszkający w Azji i Libii Cyrenejskiej Żydzi cierpieli od miast tamtejszych wielkie krzywdy. Dawniejsi królowie przyznawali im równe prawa"38.

Historyk żydowski przywołuje również świadectwo Stratona, różniące się znacznie od przytoczonego twierdzenia:

„W mieście Cyrenie ${ }^{39}$ były cztery [klasy] - jedna [klasa] obywateli, druga rolników, trzecia metoików, czwarta Żydów" ${ }^{40}$.

W Cyrenie Judejczycy tworzyli, jak zresztą w innych miejscach ówczesnego

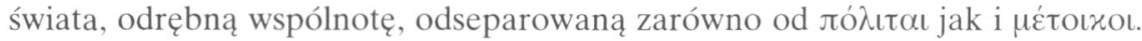
Nie byli więc pełnoprawnymi obywatelami.

Wielka metropolia starożytnego świata Antiochia miała liczną diasporę żydowską. Źródła, a przede wszystkim Józef Flawiusz, żongluje dwuznacznym określeniem „Antiocheńczyk”, oznaczającym mieszkańca tego miasta, jak i jego pełnoprawnego obywatela ${ }^{41}$. Według tego historyka:

„Żydzi dostąpili czci [...] od królów Azji, gdy brali udział w ich wyprawach wojennych. Seleukos Nikator (Zwycięzca), na przykład, obdarzył ich obywatelstwem w miastach, które założył w Azji i dolnej Syrii, i także w samej stolicy Antiochii, i nawet zrównał ich pod względem przywilejów z zamieszkałymi tam Macedończykami i Grekami, a ich uprawnienia obywatelskie przetrwały do dziś," ${ }^{2}$.

Świadectwa autora Wojny Żydowskiej nie potwierdzają inne źródła, w których brak wzmianki o pomocy militarnej udzielonej Seleukosowi I przez Greków lub przedstawicieli innych nacji. „Grecy” niewątpliwie są synonimem obywateli

oraz stosunek Żydów do kultury hellenistycznej opisuje J.M.G. Barcalay, Jews in the Mediterranean Diaspora: from Alexander to Trajan (323 BCE - 117 CE), Edinburgh 1996.

37 Por. np. Inscriptiones Graecae ad res Romanas pertinentes I 1024.

38 Antiquitates Judaicae XVI 6, 1, 160, thum. E. Dąbrowski: Józef Flawiusz, Dawne dzieje Izraela, Poznań 1979, 766.

39 Ok. roku 85 przed Chrystusem.

40 Antiquitates Judaicae XIV 7, 2, 115, tłum. Dąbrowski, s. 666.

${ }^{41}$ Por. Contra Apionem II 38-39, thum. J. Radożycki: Józef Flawiusz, Przeciw Apionowi Autobiografia, Poznań 1986, 63: „Wszyscy wezwani do osiedlania się w jakiejś kolonii, bez względu na to, jak bardzo różniliby się pochodzeniem, otrzymują nazwę od założycieli [...] [Żydzi] zamieszkali w Antiochii nazywają się Antiocheńczykami, ponieważ prawa obywatelskie nadał im jej założyciel Seleukos”. Kwestia podkreślona w: Adinolfi, Stato civile dei cristiani „forestieri e pellegrini”, s. 428.

42 Antiquitates Judaicae XII 3, 1, 119, tłum. Dąbrowski, s. 571. 
miasta, czego nie można powiedzieć o „Macedończykach”43 czyli żołnierzach stacjonujących w $\pi$ ó $ı$, a więc automatycznie poza wspólnotą obywateli. Żydzi antiocheńscy posiadali pewne przywileje, lecz to nie było równoznaczne z posiadaniem przez nich obywatelstwa.

Aleksandria ${ }^{44}$ stanowi dla współczesnych badaczy „,poligon badawczy” nad

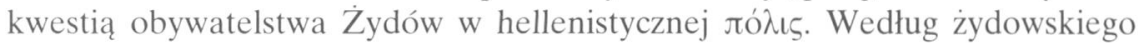
historyka Józefa Flawiusza to Aleksander Macedoński udzielił przywilejów Żydom aleksandryjskim ${ }^{45}$. Z innych wzmianek tego autora zdaje się wynikać, że odrębną dzielnicę i przywilej równouprawnienia Żydzi uzyskali jednak raczej od Ptolemeusza I Sotera ${ }^{46}$ :

„Ptolemeusz [...] w Aleksandrii zrównał ich [Hebrajczyków] w prawach obywatelskich z Macedończykami" ${ }^{47}$.

Życzliwość okazywana przez władców Żydom przedłużała się w okresie rzymskim:

„,esarze nie przestali ich darzyć największym zaufaniem, jakie okazywali im niegdyś królowie, mianowicie powierzając im straż nad rzeką [Nilem] i całą okolicą, gdyż nie uważali ich bynajmniej za niegodnych spełniania tego zadania" ${ }^{\text {, }}$.

Uprzywilejowana pozycja społeczna członków wspólnoty hebrajskiej, stanowiących między innymi ważny element w armii ptolemejskiej, wyrażała się także w wysokim poziomie intelektualnym. Poziom kultury aleksandryjskich Żydów „był równy Grekom”49. Przywileje jednak nie oznaczały zrównania w prawach. Żydzi nie posiadali prawa obywatelstwa, chociaż mieli szeroką autonomię i rządzili się własnymi prawami. Była to politeia żydowska ${ }^{50}$, nie stanowiąca zasady prawnej ani obywatelskiej, lecz odwołująca się do indywidualnego statusu i sposobu życia zgodnego z nakazami Tory.

W liście cesarza Klaudiusza do prefekta Lucjusza Emiliusa Rektusa ${ }^{51}$ znaleźć można wzmianki o kontrowersji pomiędzy Żydami i pozostałymi miesz-

43 Określenie to nie oznacza narodowości, lecz osoby pełniące służbę wojskową.

44 Ogólne dzieje Żydów w Egipcie przedstawia J. Mélèze-Modrzejewski, Żydzi nad Nilem. Od Ramzesa II do Hadriana, Biblioteka Zwojów. Tło Nowego Testamentu 3, Kraków 2000.

45 Por. Contra Apionem II 4.

46 Por. Bellum Judaicum II 488.

47 Antiquitates Judaicae XII 1, 1, 1, tłum. Dąbrowski, s. 560.

48 Contra Apionem II 5, 64, tłum. Radożycki, s. 65. Na temat statusu prawnego Żydów por. A. Kasher, The Jews in Hellenistic and Roman Egypt. The Struggle for Equal Rights, Tübingen $1985,208-232$.

49 Philo Alexandrinus, Vita Moysis I 34

${ }^{50}$ Przed cesarzem Kaligulą znany filozof i egzegeta Filon z Aleksandrii bronił praw Żydów i ich politei, por. jego Legatio ad Caium. Petycja Filona nie miała jednak na celu wywalczenia całkowitej niezależności wspólnoty żydowskiej lub zrównania w prawach obywatelskich.

51 Dokument ten odkryto w 1920 roku. Przechowywany jest obecnie w Muzeum Brytyjskim w Londynie. Opublikował go H.I. Bell, Jews and Christian in Egypt. The Jewish troubles in 
kańcami Aleksandrii. Cesarz nie ocenia faktów, lecz stara się o uspokojenie nastrojów ${ }^{52}$, odwołując się do ustawodawstwa Oktawiana Augusta, który „nie zabronił im [Żydom] prawa wybierania etnarchów, pragnąc, aby wszyscy jego poddani mogli zachowywać swoje obyczaje i nie byli zmuszani do gwałcenia swojej wiary ojczystej”. Cesarz Klaudiusz zarządza, aby Żydzi „nie byli pozbawieni żadnego z przyznanych im praw, lecz aby zachowali przywileje, które dawniej mieli i aby mogli pozostać wiernymi swoim obyczajom ojczystym" ${ }^{\text {" }}$. Grecy nierzadko oskarżali Judejczyków o separatyzm i postawy aspołeczne

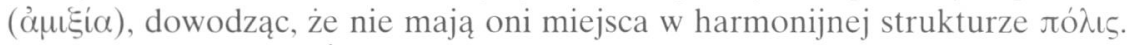

Swoje przywileje Żydzi w diasporze zachowali nawet po upadku świątyni jerozolimskiej w 70 roku. Józef Flawiusz relacjonuje:

„Aleksandryjczycy i Antiocheńczycy daremnie prosili [cesarzy] o to, żeby Judejczykom odebrano prawa obywatelskie. Fakt ten może dać wyobrażenie o łagodności i szlachetności Rzymian, zwłaszcza Wespazjana i Tytusa: chociaż doznali ciężkich trudów w wojnie z Judejczykami i byli przeciw nim rozjątrzeni za to, że przeciwnicy nie złożyli broni, lecz walczyli aż do końca - jednak nie odebrali im dotychczasowych praw obywatelskich... Umieli wznieść się ponad swój gniew, jak i ponad żądania ludu Aleksandrii i Antiochii; chociaż te miasta były bardzo silnymi gminami, ani życzliwość dla nich, ani odraza do ludu, przeciw któremu walczyli, nie skusiła Rzymian do unicestwienia którejkolwiek z lask, jakich niegdyś doznali ${ }^{\prime 54}$.

W końcowym okresie panowania Trajana diaspora judaistyczna podniosła bunt $^{55}$, a $\mathrm{z}$ chwilą śmierci cesarza powstanie wybuchło ze wzmożoną siłą. Krwawe zakończenie rebelii było dla wspólnoty żydowskiej w Egipcie prawdziwą katastrofą. Bezpośrednio po zakończeniu walk, Rzymianie skonfiskowali tereny „należące wcześniej do Judejczyków” ${ }^{\text {56 }}$. Najbardziej niszczące skutki diaspora żydowska odczuła nie tylko z powodu straty tysięcy swych członków, poległych na polu walki i na arenach cyrkowych, lecz również przez rozwiązanie ważnych instytucji, jak trybunał sądowy. Było to równoznaczne z obaleniem tradycyjnego przywileju nadanego Żydom, którzy prowadzili procesy według własnych zasad prawa religijnego. Hebraizm diaspory coraz bardziej tracił

Alexandria and the Athanasian controversy illustrated by texts from Greek papyri in the British Museum, Oxford 1924, 1-37; por. G. De Sanctis, Claudio e i Giudei d'Alessandria, „Rivista di Filologia e di Istruzione Classica” 52 (1924) 473-513; F. Cumont, La lettre de Claude aux Alexandrins, RHR 91 (1925) 3-6.

${ }^{52}$ Winna być zapewniona Żydom swoboda w praktykowaniu religii, por. P.W. Pestman, The New Papyrological Primer, Leiden - New York - Kobenhaven - Koeln 19905, nr 16, s. 107-108.

53 Antiquitates Judaicae XIX 1, 2, tłum. Dąbrowski, s. 903.

54 Tamże XII 3, 1, 119 tłum. Dąbrowski, s. 571.

${ }^{55}$ Dokładną analizę historyczną tych wypadków przedstawia M. Pucci, La rivolta ebraica al tempo di Traiano, Piza 1980; por. również A. Fuks, Aspects of the Jewish revolt in A.D. 115-117, JRS 51 (1961) 98-104, spec. 101.

${ }^{56}$ Por. V. Tcherikover - A. Fuks - M. Stern, Corpus Papyrorum Judaicarum, II, Jerusalem Cambridge (Mass.) 1957-1964, 445. 
swoją tożsamość przez asymilację swych członków. Był to proces tak głęboki, że można nawet mówić o unicestwieniu wspólnoty żydowskiej ${ }^{57}$. Tym samym zniknęła politeia, którą Żydzi szczycili się przez stulecia. Jej miejsce zajął judaizm rabinistyczny.

Znamienny jest fakt, że tradycja judaistyczna uznała, że wyobcowanie jest najlepszą sytuacją dla doskonalenia się duchowego członka narodu wybranego. Filon Aleksandryjski przyznaje koncepcji ,pielgrzymowania” i „,wyobcowania” bardzo ważne miejsce w swojej wizji duchowej. Tematyka ta, co prawda, jest rozproszona w wielu dziełach uczonego Żyda, lecz wyraźnie widać, że opracowania przez niego koncepcja wywodzi się z diatryby cyniczno-stoickiej oraz platonizmu. Aleksandryjski Żyd wskazuje, że człowiek wierzący przebywa na tej ziemi jako cudzoziemiec, bowiem, ,tylko Bóg jest prawdziwie obywatelem, podczas gdy każde ze stworzeń jest tylko przybyszem i obcym" "58; biblijnymi wzorami wędrowców i wyobcowanych są Abraham i Mojżesz ${ }^{59}$.

Niewątpliwie więc mentalność członków diaspory żydowskiej wpłynęła w pewien sposób na chrześcijan, zarówno pochodzących z narodu wybranego, jak i z pogan. Nowy Testament poświadcza, że czuli się pod względem religijnym „obcymi” i „przechodniami” na tym świecie. Większości z nich była także „cudzoziemcami” w ówczesnych miastach. W większości pozbawieni obywatelstwa, tak przecież trudnego do uzyskania, żyli na marginesie życia politycznego, jako rezydenci bez pełni praw w Egipcie, Poncie, Galicji, Kapadocji, Azji Mniejszej i w Rzymie.

3. Powstawanie eklezjologii ,obcości”. W 1. poł. II wieku chrześcijaństwo składało się jeszcze z mniejszości żyjących w warunkach politycznej i społecznej separacji. Świadomość wyobcowania z tego świata podtrzymywały prześladowania ze strony Żydów i pogan. Eklezjologii nadała więc kierunek samoświadomość chrześcijan, że przebywają jako obcy na tym świecie ${ }^{60}$. Wyrażają to na przykład w listach, które między sobą wymieniały pierwsze wspólnoty. Słynny list papieża Klemensa do wspólnoty w Koryncie rozpoczynał się w ten sposób:

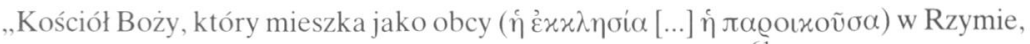
do Kościoła Bożego, który mieszka jako obcy w Koryncie"61.

57 Por. E.M. Smallwood, The Jews under Roman Rule, Leiden 1976, 405-406.

58 Philo Alexandrinus, De Cherubim et flammeo gladio 121; por. również jego De confusione linguarum 76-82; De somniis I 180; Quis rerum divinarum heres sit 267-268.

59 Starotestamentowemu patriarsze poświęca on aż dwa traktaty: De migratione Abrahami i De Abrahamo, które stały się inspiracją dla autorów chrześcijańskich; por. interesujące studium T. Seland, Strangers in the Light: Philonic Perspectives on Christian Identity in 1 Peter, Leiden 2005.

${ }^{60}$ Por. C. Andresen, Die Kirchen der alten Christenheit, Stuttgart 1971, 17-19.

${ }^{61}$ I Epistula ad Corinthios prol., SCh 167, 98, tłum. A. Świderkówna, BOK 10, Kraków 1998 , s. 82 , nota 1 oraz s. $420-421$ (słowniczek). 
Zawiadamiając braci z innego miasta o męczeństwie św. Polikarpa biskupa, chrześcijanie ze Smyrny pisali:

„Kościół Boży, który mieszka jako obcy ( $₫ \propto \varrho o เ x o v ̃ \sigma \alpha)$ w Smyrnie, do Kościoła Bożego, który mieszka jako obcy w Filomelion i do wszystkich wspólnot zamieszkały jako obce na całym świecie" $"$.

Podobnie rozpoczyna swój list Polikarp, biskup Smyrny:

„Polikarp i wszyscy starsi obecni przy nim do Kościoła Bożego pielgrzymującego (

Chodzi tu o formuły wprowadzające, ukazujące jednak, jak głęboko była zakorzeniona świadomość „wyobcowania” w Kościołach rozsianych po ówczesnej ekumene. Kościoły były więc wspólnotami pielgrzymującymi w każdym zakątku świata, wezwanymi do świadczenia o niebiańskiej ojczyźnie i eschatologicznym wymiarze nadziei chrześcijańskiej. Jak można wywnioskować ze słownictwa II wieku nastąpiła ewolucja, która doprowadziła do tego, że jako „mieszkające na obczyźnie” kwalifikowano wspólnoty lokalne ${ }^{64}$. Stąd też użycie specyficznej terminologii nie znamionuje chęci wskazania na status społeczno-prawny chrześcijan.

Teofil z Antiochii przedstawia wspólnoty chrześcijańskie jako ośrodki diaspory, czyli jako wyspy na wzburzonym morzu świata:

„Jak na morzu są pewne wyspy możliwe do zamieszkania, zaopatrzone w wodę i urodzajne, wyposażone w przystanie i porty, by miotani sztormami mogli się w nich schronić, tak również Bóg udzielił światu, który jest miotany i rzucany grzechami, miejsca modlitwy zwane także świętymi wspólnotami (Kościołami), w których jak w portach wysp są przechowywane nauki prawdy" ${ }^{\prime 65}$.

Ciekawym elementem jest to, że chrześcijański apologeta ujawnia zależność od mądrościowej literatury schyłkowego judaizmu ${ }^{66}$. Samoświadomość i samook-

${ }^{62}$ Martyrium Polycarpi prol. SCh 10, 210, przekład własny, por. tłum. A. Świderkówna, BOK

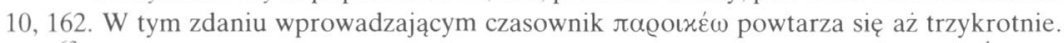

63 Epistula ad Philippenses prol., SCh 10, 176, przekład własny, por. tłum. A. Świderkówna, BOK $10,156$.

${ }^{64}$ Potwierdza to dokumentacja epistolarna przedstawiona u Euzebiusza z Cezarei (HE IV 18, 9; 23, 5; V 24, 14). Greckie określenie $\pi \alpha$ @oıxí $\alpha$ stanowi bazę dla łacińskiego słowa paroecia, oznaczającego parafię. Z czasem słowo „parafia” zaczęło oznaczać po prostu jedynie jakiś teren, jakiś okręg administracyjny Kościoła lokalnego. Taka terminologia jak „,parafianie" i ,proboszcz” zaczęła określać członków wspólnoty oraz odpowiedzialnego czy też administratora parafii, już bez jakiegokolwiek odniesienia do pojęcia „pielgrzym” i „obcy” lub wykonujący pewne posługi wobec pielgrzymów.

65 Ad Autolycum II 14, 3, SCh 20, 136, przekład własny.

${ }^{66}$ Opinia Kretschmara cytowana w: J. Daniélou, Teologia judeochrześcijańska, tłum. S. Basista, Kraków 2002, 135. 
reślanie się chrześcijan oraz Żydów nawet w okresie silnych kontrowersji zachowuje punkty zbieżne.

Potwierdza to starożytna homilia zwana 2 Listem Klemensa. Wyobcowanie chrześcijan na świecie postrzegane jest w tym dziele w kontekście antagonizmu istniejącym pomiędzy obecnym światem a przyszłym:

„Porzućmy nasze doczesne mieszkanie i nie lękajmy się wyjść z tego świata... Nasz pobyt w ciele na tym świecie to rzecz mała i trwa krótko, a obietnica Chrystusa jest wielka i przedziwna" ${ }^{67}$.

Obcość uczniów Chrystusa pojawia się również w Liście do Diogneta, ale jest łagodzona świadomością odpowiedzialności chrześcijan za losy świata:

„Chrześcijanie nie odróżniają się od innych ludzi ani jakimś specjalnym terytorium, ani językiem, ani zwyczajami. Nie zamieszkują osobnych miast, nie mają własnego języka, nie prowadzą jakiegoś osobliwego trybu życia [...]. Mieszkają w miastach zarówno greckich jak i barbarzyńskich, jak komu wypadnie, i mimo ze w ubiorze, jedzeniu i we wszystkich innych sprawach idą za zwyczajami miejscowymi, prowadzą tryb życia wspaniały $i$, jak to wielu wyznaje, niewiarygodny. Mieszkają w swojej ojczyźnie, ale jakby byli cudzoziemcami; wykonują wszystkie obowiązki dobrego obywatela i nie uchylają się od żadnych ciężarów, ale czynią to jakby byli przyjezdnymi gośćmi. Każda obca ziemia jest dla nich ojczyzną, każda ojczyzna jest dla nich obcą ziemią [...]. Żyją na tej ziemi, ale czują się obywatelami nieba. Są posłuszni ziemskim prawom, ale ich sposób życia wynosi ich ponad wszelkie prawo [...]. Żydzi ustawicznie toczą z nimi wojnę, poganie ich prześladują. Ale ci, którzy ich nienawidzą, nie potrafią powiedzieć, jaki jest powód ich wrogości. Słowem, chrześcijanie są dla świata tym, czym dusza jest dla ciała. Bóg ich umieścił w tym zaszczytnym miejscu i oni nie mogą stamtąd zdezerterować" 68 .

Anonimowemu autorowi chodzi o swoisty rodzaj „obcości”. Nie wchodzą tu w grę elementy platońskie i gnostyckie, określające człowieka jako nawet ,Z natury swej obcego dla świata". Przedstawiciele heterodoksyjnej gnozy głosili często, że świat jest dziełem złego demiurga i dlatego zalecali powstrzymanie się od zaangażowania w sprawy doczesności przez pracę, zakładanie rodziny i uczestnictwo w życiu publicznym. Obcość chrześcijańska ma charakter eschatologiczny, a nie ontologiczny. Wierzący odczuwają swą odrębność z powodu swego powołania, nie są obcymi przez naturę; są przeznaczeni do innego świata. Chrześcijańskie rozumienie obcości opiera się na zmartwychwstaniu Chrystusa: „Jeśli z Chrystusem powstaliście z martwych, szukajcie tego, co w górze" (Kol 3,1). Chrześcijanin nie jest więc miotany konfliktami wewnętrznymi, czy wyprzeć się miasta swego ziemskiego pochodzenia. Dylematy dotyczą natomiast sfery wewnętrznej i moralnej.

67 Epistola II Ps-Clementis 5, PG 1, 336, tłum. A. Świderkówna, BOK 10, 94.

68 Ad Diognetum V 1-2; 4-5; 9-10; VI 1 i 10, SCh 33, 62-66, przekład własny, por. thum. A. Świderkówna, BOK 10, 341-342. 
Obok Listu do Diogneta rozważania Ireneusza z Lyonu stanowią kamień milowy w refleksji na temat statusu „wyobcowania” chrześcijan. Autor ten łączy postać patriarchy Abrahama z naśladowaniem Słowa (sequela Verbi):

„Abraham, po opuszczeniu wszystkich swoich bliskich na tej ziemi, podążał za Słowem, czyniąc się cudzoziemcem ze Słowem, aby stać się współobywatelem Słowa" ${ }^{\circ 9}$.

W końcowej części Adversus haereses biskup Lyonu konkluduje, mówiąc, że starotestamentowy patriarcha jest „ojcem tych wszystkich, którzy naśladują Słowo Boga, godząc się z tym, że żyją jako obcy na tym świecie" 70 . Ireneusz po raz pierwszy w literaturze chrześcijańskiej używa czasownika $\xi \varepsilon v ı \varepsilon v ́ \omega$, aby wskazać na sposób życia cudzoziemca i wyobcowanego ${ }^{71}$. Późniejsza tradycja, jak się wydaje, nie wniosła znaczącego wkładu do nauczania odnoszącego się do „wyobcowania" chrześcijan, obecnych jednak w sposób aktywny w dziejach świata.

Pisarze aleksandryjscy rozwijali natomiast ideę Kościoła jako doskonałej лó̀ı s. Klemens z Aleksandrii odwoływał się do stoików:

„,powiadają, że tylko niebo jest właściwym państwem, wszystko zaś, co na ziemi tutaj, to nie są jeszcze państwa; wprawdzie są tak nazywane, ale nie są nimi" ${ }^{72}$.

Przyjmuje ponadto koncepcję państwa monarchicznego, gdzie władzę sprawuje

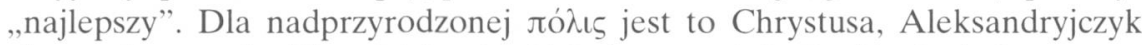
akcentuje te cechy Zbawiciela, dzięki którym spełnia On ideał władcy poszukiwany przez helleńskich myślicieli.

Orygenes mówi o Kościołach partykularnych rozsianych po całej ziemi. Jednak w tym przypadku ta dobrze znana konstatacja nie prowadzi autora do rozwinięcia wątku o diasporze chrześcijańskiej i wyobcowaniu wiernych, lecz do szukania zasady duchowej jedności. Aleksandryjczyk kładzie ponadto nacisk na specyfikę wspólnot chrześcijańskich:

„Kościoły Boże [...] jeśli się je porówna ze zgromadzeniami ludowymi, z którymi sąsiadują, są jak «światła na ziemi» (Flp 2, 15). Ci, którzy w Kościele są mali [...]

69 Adversus haereses IV 5, 3-4, SCh 100, 434-437.

70 Adversus haereses IV 25, 1, SCh 100, 704.

${ }^{71}$ Dla biskupa Lyonu postacią reprezentatywną dla wyobcowanych ze świata jest Abraham. Potwierdza to także Demonstratio apostolicae praedicationis 24; 35 i 44. Z późniejszych autorów Jan Chryzostom wskazuje na przykład tego patriarchy i zachęca, aby życie ludzkie uważać za pielgrzymkę ku wiecznej ojczyźnie, por. O. Pasquato, I laici in Giovanni Crisostomo. Tra Chiesa, famiglia e città, Roma 1998, 202.

72 Stromata IV 172, 2-3, GCS 52, 324-325, tłum. J. Niemirska-Pliszczyńska: Klemens Aleksandryjski, Kobierce, Warszawa 1994, 394. Autor ten przytacza ponadto (tamże) własną definicję

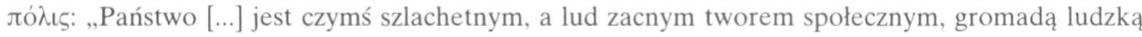
zarządzaną przez prawo, jak przez Logos - Kościół, który jest państwem na ziemi nie do zdobycia, nie do opanowania przez tyranię, wyrazem woli Bożej na ziemi, jak i w niebie", por. również Plato, IX 592B. 
przewyższają jednak wielu tych, którzy biorą udział w zgromadzeniach ludzi [obywateli polis]",73.

W ujęciu Orygenesa zasadnicza różnica pomiędzy zgromadzeniami o charakterze religijno-politycznym i Kościołami była już tak ugruntowana i zrozumiała, że nie wymagała komentarza i szczegółowszej analizy. To samo winni byli dostrzegać oponenci Kościoła, dla których pogański myśliciel Celsus był punktem odniesienia ${ }^{74}$.

Mimo faktu, iz początkowo pojęcie wspólnoty wierzących łączono z ideą „diaspory" i wyobcowania, dzięki wpływowi autorów aleksandryjskich coraz częściej zaczęto postrzegać Kościół jako harmonijny organizm czy też wzór idealnej i duchowej лó̀ı५.

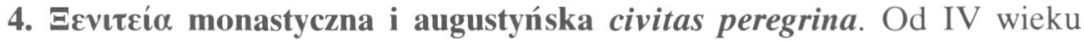
następuje zmiana położenia chrześcijaństwa i wartościowania rzeczywistości doczesnej. Ta ostatnia wydawała się tym bardziej do zaakceptowania, iz pojawiła się w historii szczególnego rodzaju zdobycz: wolność religijna ${ }^{75}$. Chrześcijanie nie są od tej pory „przeciwko światu” lecz „w świecie”. Powoduje to, że idea „wyobcowania” i ,pielgrzymowania” nabiera nowych odcieni i znaczeń w monastycyzmie ${ }^{76}$. To właśnie pierwsi mnisi nawiązywali do postaci Abrahama jako ideału posłusznego Bogu człowieka wiary ${ }^{77}$ oraz praktykowali oddalenie od ojczyzny, skupisk ludzkich i możliwości ofiarowanych przez cywiliza-

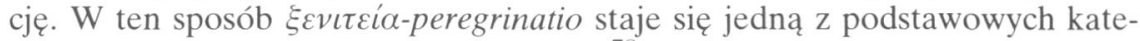
gorii duchowości i praktyki monastycznej ${ }^{78}$.

Wybierając życie doskonalsze, zdaniem św. Hieronima, mnich powinien być nie tylko „obcym” w sensie duchowym, ale także dosłownym ${ }^{79}$. Stąd też

73 Contra Celsum III 29, GCS 2, 227, przekład własny.

${ }^{74}$ Według relacji Orygenesa, Celsus jawi się jako epikurejczyk pozostający pod wpływem średniego platonizmu i nie stroniący od zasad stoicyzmu.

75 Por. przede wszystkim R. Farina, L'impero e l'imperatore cristiano in Eusebio di Cesarea, Zurich 1966.

76 Jan Klimak (Scala Paradisi 3, PG 88, 664) definiuje „wyobcowanie” jako „nieodwracalne opuszczenie tego wszystkiego, co w naszej ojczyźnie przeszkadza nam osiągnąć cel naszej wiary”. Wiadomo, że „mnich nie może osiągnąć doskonałości w swojej ojczyźnie” (Hieronymus, Epistula 14, 7, PL 22, 352A).

77 Św. Antoni Egipski, ,ojciec mnichów”, przede wszystkim naśladował Chrystusa, por. Athanasius Alexandrinus, Vita Antonii 2. Jednak już w Listach, które przypisuje mu tradycja monastyczna, odnośniki do powołania i wędrówki Abrahama są bardzo wyraźne, zob. Epistula 1, 1 (aluzja do Rdz 12,1). Jan Kasjan przenosi te idee na grunt łaciński, por. Conlationes III 3-4 i 6.

78 Por. A. Guillaumont, Le dépaysement comme forme d'ascèse dans le monachisme ancien, w: tenże, Aux origines du monachisme chrétien, Bellefontaine 1979, 89-116.

79 Por. Hieronymus, Epistula 14, 7, PL 22, 352A: „Monachum in patria sua perfectum esse non posse. Perfectum autem esse nolle, derelinquere est". Słowa te zostały skierowane do Helio- 
wielu opuszczało rodzinne strony, udając się w nieznane kraje, gdzie, jako nieznani i lekceważeni przez autochtonów, szukali łączności z Bogiem. Historyk chrześcijański Sozomen kwalifikuje mnichów jako „cudzoziemców” na tym świecie, którzy są tutaj tylko chwilowo ${ }^{80}$. Należy więc zerwać ze światem i przyjaźniami z zewnątrz ${ }^{81}$. Znakiem obcości w otaczającym świecie będzie specjalny i jednolity strój mnisi ${ }^{82}$.

Konkretne przykłady życia mnichów ukazywały, że pojęcie wyobcowania zostało zinterioryzowane, chociaż konkretna realizacja ideału mogła być wyjaśniona uwarunkowaniami kulturowymi i socjologicznymi. W Egipcie, gdzie dominował model kultury rolniczej, mnisi wywodzący się z ludu byli z natury samotnikami, zachowywali milczenie i niechętnie opuszczali miejsce swego odosobnienia. Ich $\xi \varepsilon v i \tau \varepsilon i \alpha$ miała charakter wewnętrzny, byli oni bowiem umiarkowani w ascezie i rozważni w nauczaniu. Natomiast na mnichów syryjskich wpłynęło środowisko wędrowców i kupców ${ }^{83}$. Stąd też asceci syryjscy chętnie przemieszczali się, uważając wędrówki za jeden z integralnych elementów ich formacji ${ }^{84}$. Celem mniszych podróży były znane ośrodki monastyczne w Egipcie i sławni asceci. Dla mnichów syryjskich wędrowanie i zmiana miejsca pobytu to główne elementy realizacji doskonałości chrześcijańskiej. Potwierdzeniem tego jest fakt określania mnichów jako tych „którzy wędrują" 85 . Nie należy zapominać, że te dwie różne formy wyobcowania ze świata przenikały się, a nawet otrzymywały nowe rysy w odmiennych warunkach ${ }^{86}$.

Jednak na Wschodzie i Zachodzie dochodziło do nadużyć i wędrówki ascetyczne stawały się pretekstem do włóczęgostwa i życia pasożytniczego. Z tego powodu św. Benedykt zdecydowanie reagował przeciwko „mnichom-włóczęgom" ${ }^{87}$. Niewątpliwie $\xi \varepsilon v ı \varepsilon \varepsilon i \alpha$ wymagała od praktykujących ją zrównoważenia

dora. Paulin z Noli (Epistula 5, 14, CSEL 29, 34) zachęcal jednego ze swoich adresatów: „Idź na obczyznę (peregrineris), daleko od twojej ojczyzny, aby wzrastały łaska i miłość, bo chociaż jeszcze twoje ciało jest twoim mieszkaniem, jesteś na wygnaniu (peregrinaris), daleko od Chrystusa".

${ }^{80}$ Por. HE I 12.

${ }^{81}$ Por. Basilius, Regulae fusius tractatae 8, 1.

${ }^{82}$ Por. tamże 22,2-3. W monastyrach bazyliańskich nie praktykowano handlu, zob. tamże 38.

${ }^{83}$ Ewangelizacja, która stała się udziałem Kościoła syryjskiego, następowała wzdłuż szlaków handlowych.

${ }^{84}$ Prototypami tego typu ascezy były grupy charyzmatyków i wędrownych proroków w Syrii Palestynie. Zidentyfikowano także wpływy apokryficznych pism, jak np. Dzieje Tomasza, Liber graduum i Ewangelia Tomasza, por. M. Mees, Pilgerschaft und Heimatlosigkeit. Das frühe Christentum Ostsyriens, „Augustinianum” 19 (1979) 53-73.

${ }^{85}$ Por. E. Lanne, Peregrinatio, DIP VI 1429.

${ }^{86}$ Wśród mnichów łacińskich w V wieku wędrowanie z miejsca na miejsce było bardzo popularne. W kolejnym stuleciu dla ascetów irlandzkich wędrówki do obcych krajów i nieznanych ludów stały się czymś naturalnym, por. Walafrid Strabo, Vita S. Galli II 46; zob. też H. Leclercq, Gall [saint], DACL VI 79, nota 6, gdzie znajdują się wszystkie główne odnośniki do źródeł.

87 Por. Regula S. Benedicti I 10-12. 
i wyrobienia duchowego. Duchowość monastyczna była jednak elitarna. Tak więc, chociaż rozwinięto obraz chrześcijan jako przechodniów i pielgrzymów na tym świecie, zatracał się aspekt eklezjalny. Nie można jednak powiedzieć, że „sensus Ecclesiae” był obcy autorom z kręgów monastycznych.

Przykłady szerszego pojmowania pielgrzymującej wspólnoty wiernych daje św. Augustyn z Hippony. Na tory eklezjalne wprowadza jego refleksja o civitas peregrina. Wychodzi ona z przesłanek dotyczących sytuacji każdego wierzącego:

„Cóź powiada Apostoł odnośnie do obecnej sytuacji? «Dopóki jesteście w ciele, pielgrzymujemy do Pana» (2Kor 5, 6). Jeszcze nie jesteśmy w ojczyźnie. Kiedy w niej będziemy? Kiedy odniesiemy zwycięstwo, pokonawszy nieprzyjaciela diabła, kiedy «jako ostatni wróg zostanie pokonana śmierć»" 88 .

Interpretacja powyższa nie różni się zasadniczo od poglądów większości pisarzy chrześcijańskich, ujmujących w podobny sposób stan chrześcijan w świecie. Biskup Hippony podkreśla jednak, że poprzez odrodzenie przez laskę:

„narodził się obywatel miasta Bożego, pielgrzym na tym świecie, przeznaczony przez łaskę i dzięki niej wybrany; z przyzwolenia pielgrzym tutaj [na ziemi], a z łaski obywatel tam, w górze" $"$.

Wzmianka o pełnoprawnym obywatelstwie chrześcijan to najwyrazistsze i najmocniejsze sformułowanie, jakim dysponowali ludzie należący do kultury rzymskiej. Owa przynależność bowiem zakładała lojalność wobec nadprzyrodzonej rzeczywistości, analogicznie do posłuszeństwa obywateli władzy zwierzchniej w imperium. Ideał zachowania wierności cesarstwu przez obywateli, szczególnie zaś urzędników, zostaje przeniesiony na płaszczyzną ducha. Lojalność wobec ideałów niebiańskiego Jeruzalem winna być zachowana mimo przeszkód i wmieszania się w sprawy tego świata ${ }^{90}$.

Wpływom mentalności platońskiej ${ }^{91}$ należy przypisać wzajemną relacją pomiędzy pielgrzymującymi a niebiańską społecznością. W istocie:

„ci, którzy wzdychają w tym życiu, i pożądają owej ojczyzny, niechaj biegną przez miłość, a nie nogami cielesnymi. Niechaj nie szukają okrętów, ale skrzydeł. Miłość niechaj posługuje się dwoma skrzydłami. Jakież to są dwa skrzydła miłości? Miłość Boga i bliźniego. Albowiem wędrujemy, wzdychamy, jęczymy, Przyszły do nas listy ${ }^{92}$ z naszej ojczyzny, to je wam odczytujemy"93.

88 Enarrationes in Ps. 148, 4, CCL 40, 2168, tłum. J. Sulowski, PSP 42/1, 373.

89 De civitate Dei XV 1, CCL 48, 453-454.

${ }^{90}$ Por. Enarrationes in Ps. 61, 8.

91 W pismach Augustyna nie brak jednak krytyki platonizmu, por. A. Trapé, Escatologia e antiplatonismo di sant'Agostino, ,Augustinianum” 18 (1978) 237-244.

92 Augustyn utożsamia „Boskie listy” z Pismem Świętym, por. Enarrationes in Ps. 73, 5; 127, 9.

93 Tamże 149, 5, CCL 40, 2181, PSP 42/1, 388. 
Dla „pielgrzymującego ku wieczności”,94 czas dzieli się więc na „pielgrzymowanie” i „przebywanie z ojczyźnie”. Wszędzie jednak widać opiekę Boga, który „rozumie ich niewolę i pokazał im inne państwo, do którego powinni wzdychać, któremu powinni poświęcać wszelkie wysiłki i do którego powinni nakłaniać własnych obywateli i współtowarzyszy drogi, aby razem móc je zdobyć" 95 . Biskup Hippony przekonuje, że „,kto nie wzdycha jako pielgrzym, ten nie będzie się cieszył jako obywatel, ponieważ tego nie pragnie"

Będący świadomi swojej odrębności, chrześcijanie winni uważać się za część civitas peregrina, czyli za mieszkających czasowo na ziemi i przechodniów. To właśnie oni, ,żyjąc według Boga, są pielgrzymami na ziemi (secundum Deum viventes peregrinantur in terris) ${ }^{\prime 97}$. Każdy pielgrzym na drodze ku niebiańskiej ojczyźnie musiał tęsknić za swym właściwym domem. Augustyn oddaje te nastroje, mówiąc o Żydach w niewoli babilońskiej wyglądających dnia powrotu do ojczyzny ${ }^{98}$, lecz zaznacza, że pragnienie osiągnięcia niebiańskiej Jerozolimy widoczne jest w całej historii Starego Testamentu. W rzeczywistości już „,[pierwszy] człowiek [ponieważ został] zaprzedany grzechowi stał się wędrowcem: z jego rodu powstał rodzaj ludzki" 99 .

Fakt pielgrzymowania ku niebiańskiej ojczyźnie zakłada cierpienie, prześladowanie i niespełnienie. Jest się jednak coraz bliżej osiągnięcia celu, „do którego zdążamy, póki jesteśmy wygnańcami, i gdzie będziemy się radować po zakończeniu naszej pielgrzymki. Ku temu miastu wstępuje każdy człowiek, który idzie naprzód, a oddala się od niego i upada, ten, kto przestaje iść naprzód"100. Augustyn wprowadzając analogię ze wspólnym pielgrzymowaniem i zachętę do podjęcia go przez afrykańskich chrześcijan, podkreśla aspekt wspólnotowy wędrówki ku niebiańskiej ojczyźnie. Ponadto nasz autor odwołuje się do obrazu „Kościoła otwartego”, czyli takiego, który jeszcze nie został oddzielony od zamieszania tego świata ${ }^{101}$.

Mniejszości religijne, etniczne i kulturowe w każdym społeczeństwie czują się wyobcowane. Jest jednak faktem znamiennym, że to właśnie Stary Testa-

${ }^{94}$ Por. J. Fontaine, Chrześcijańska literatura tacińska. Rys historyczny, tłum. J. Słomka, Tarnów 1997, 135.

95 Enarrationes in Ps. 136, 2, CCL 40, 1969, PSP 42/1, 145; por. również tamże 125, 9.

96 Tamże 148, 4, CCL 40, 2168, PSP 42/1, 372.

97 De civitate Dei XVII 3, CCL 48, 553, przekład własny.

98 Por. np. Enarrationes in Ps. 136, 4.

99 Tamże 125, 3, CCL 40, 1846, PSP 42/1, 15.

100 Tamże 126,1, CCL 40, 1856, PSP 42/1, 26.

101 Por. tamże 136, 2. 
ment, a za nim Nowy, uczyniły z tej sytuacji socjologicznej i prawnej cechy na wskroś duchowe. Świadomość przejściowości i wyobcowania rodziła dwa główne niebezpieczeństwa: izolowania się od świata, przez brak uczestniczenia w jego kształtowaniu i zarządzaniu. Ponadto innym poważnym niebezpieczeństwem była tendencja gnostycka do lekceważenia i odrzucenia rzeczywistości materialnej, która czyniła z idei wyobcowania łatwą drogę ucieczki w mity i złudzenia. Zarówno Nowy Testament jak i najwcześniejsi autorzy chrześcijańscy objawiają związki pomiędzy mentalnością „diaspory” judaistycznej i sytuacją poszczególnych Kościołów w świecie pogańskim. Oprócz aspektu wspólnotowego istniała również płaszczyzna indywidualna, dzięki której spoglądano na każdego chrześcijanina jak na „obcego” i „przybysza”. $\mathrm{Z}$ chwilą, gdy przestały istnieć przesłanki prawno-kulturowe wyobcowania członków Kościoła, ukształtowały się oraz ugruntowały duchowość przejściowości i eklezjologia wyobcowania. Widać to w ideale życia monastycznego postrzeganego jako „wyobcowanie” i ,pielgrzymowanie” ze względu na trudności, brak zabezpieczenia na przyszłość, ponieważ asceza była eschatologicznym znakiem pragnienia prawdziwej ojczyzny w niebie. W rozważaniach o „civitas peregrina” Doctor gratiae nawiązuje do sytuacji egzystencjalnej człowieka-pielgrzyma w doczesności. Opis niebiańskiej ojczyzny stanowi okazję, aby poruszyć kwestię wiecznego szczęścia i jednocześnie mówić o wspólnocie świętych na ziemi.

Zinterioryzowanie statusu chrześcijan jako „obcych” i „przechodniów” oraz podkreślenie wyobcowania Kościoła z logiki tego świata wydają się nadal aktualne. W każdych warunkach i w każdym czasie chrześcijanie powinni być przede wszystkim „,solą ziemi”. Pełnią takie zadanie, jeśli nie utracą swego "smaku”, to znaczy swojej odmienności w stosunku do świata. Pozostają więc zalążkiem wieczności dopóki żyją jak „obcy” i „pielgrzymi” w tym świecie.

\section{„FORESTIERI”E „PELLEGRINI” \\ DALLA POSIZIONE CIVILE E GIURIDICA ALL'ECCLESIOLOGIA} DELL'ESTRANEITÀ

(Sommario)

1Pt è scritta „ai pellegrini della diaspora”, ai quali è poi rivolta l'esortazione a comportarsi con tímore nel tempo del loro „pellegrinaggio” e ad astenersi dalle concupiscenze della carne. Alle nozioni scritturistiche va aggiunta osservazione che nella sua prima fase il cristianesimo era costituito da minoranze che vivevano tra loro in una situazione geografica di isolamento. Anche se si trattava soprattutto dell'e- 
straneità in senso religioso, non fu semplicemente una metafora, ma una costatazione sulla condizione dei cristiani come „forestieri” e „pellegrini” che rifletteva anche un particolare stato civile dei cristiani dell'epoca. I credenti avevano una forte coscienza di essere „sale della terra" e il loro „sapore” consisteva nell'alterità rispetto al mondo in cui vivevano solo di passaggio. A partire del IV secolo i concetti di estraneità e di pellegrinare nel mondo cambiano collocazione. Furono soprattutto i monaci a praticare la xenitéia che consisteva nell'abbandonare, per ragioni spirituali, il proprio ambiente per condurre la vita di straniero. Invece sant'Agostino nel concetto della „civitas peregrina” espresse l'atteggiamento interiore del credente distaccato dalla confusione di questo mondo e rivolto verso la patria celeste. La coscienza di essere „forestieri” e „pellegrini” diventò una dimensione necessaria della „conversione” evangelica dei credenti di ogni tempo. 